\title{
Hyposensitisation with house dust mite vaccine in bronchial asthma
}

\author{
JOHN GADDIE，CRAIG SKINNER，K N V PALMER
}

British Medical fournal, 1976, 2, 561-562

\section{Summary}

In a double-blind placebo-controlled trial of tyrosineadsorbed Dermatophagoides pteronyssinus vaccine no improvement was seen in 45 patients with asthma sensitive to house dust mite. In particular there was no significant improvement in symptom scores, spirometry, and skin and nasal challenge test results. Some patients in other studies have benefited from doses of vaccine much stronger than those now commercially available, but the incidence of side effects has also been high.

\section{Introduction}

In this country the commonest allergen in house dust is Dermatophagoides pteronyssinus, ${ }^{1-;}$ which is widely distributed in household dust and particularly in bedding. Although no benefit was found after hyposensitisation to house dust extract alone ${ }^{6}$ several recent studies have given more encouraging results with house dust mite extract. ${ }^{7-10}$ The incidence of side effects to the aqueous vaccine is high, however, and in one trial side effects were seen in $37.5^{\circ}$ of patients. ${ }^{10}$ To reduce this incidence a tyrosine-adsorbed depot form of $D$ pteronyssinus vaccine (Migen, Bencard) has been introduced, and we report the results of a double-blind placebo-controlled trial of this vaccine in mite-sensitive adult asthmatic patients.

\section{Patients and methods}

Fifty-five patients with perennial asthma were admitted to the trial. All had an immediate positive prick skin reaction to an extract of $D$ pteronyssinus $\left(1 \cdot 2^{\circ}, \mathrm{w} / \mathrm{v}\right)$ and either a history of symptoms provoked by household dust or a positive nasal challenge response with $D$ pteronyssinus $\left(0.33^{\circ} \% \mathrm{w} / \mathrm{v}\right)$. None had received any hypotensitisation injections in the preceding 12 months. The patients were divided into two groups (table I) by a stratified randomisation procedure that ensured that the groups were comparable in age, sex, and severity of airways obstruction. The patients' maintenance treatment was unchanged throughout the trial. All patients have previously been advised about measures to reduce exposure to household dust, in particular regular vacuum cleaning, the use of synthetic bedding material, and the enclosure of the mattress in an impervious cover.

University Department of Medicine, Aberdeen AB9 2ZD JOHN GADDIE, MD, research fellow

CRAIG SKINNER, MB, MRCP, senior medical registrar (present address: East Birmingham Hospital, Birmingham)

K N V PALMER, MD, FRCP, reader in medicine
TABLE I-Clinical features of 55 asthmatic patients

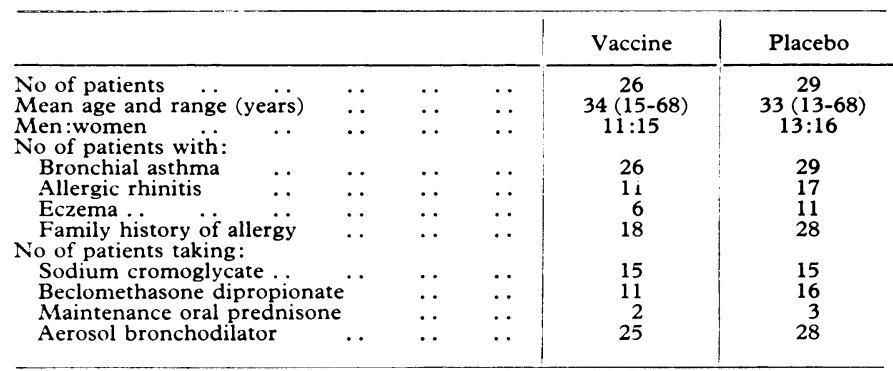

All patients received their first injection in October or November. They received six weekly injections of vaccine or placebo and booster injections every month for 12 months. The initial injection of the vaccine contained 4 Noon units rising to $10,25,60,150$, and 400 Noon units. Each subsequent monthly injection contained 400 Noon units. Any local or systemic side effects after the injections were recorded.

Patients were reviewed one, three, six, nine, and 12 months after completion of the initial course of six injections. On entry to the trial and at each review asthmatic symptoms, spirometric values, and daily use of aerosol bronchodilator were recorded and prick and nasal challenge tests with $D$ pteronyssinus extract were carried out. Symptoms recorded were day-time wheeze, night wakening due to wheeze, chest tightness, sneezing, nasal obstruction and discharge, and tolerance to house dust. Each symptom was recorded on a 0-4 scale. Spirometry was carried out on a dry wedge spirometer and no bronchodilator drugs were taken for 12 hours beforehand. The forced expiratory volume in 1 second $\left(\mathrm{FEV}_{1}\right)$ and forced vital capacity (FVC) were recorded from the best of three attempts at $10 \mathrm{am}$ at each visit to exclude the effect of diurnal variation on ventilatory function. To assess the degree of sensitivity to the house dust mite prick skin tests were carried out using four concentrations of $D$ pteronyssinus extract: $0.005^{\circ}, 0.04 \%, 0.33 \%$, and $1 \%$. Nasal challenge tests were carried out using the lowest three of these concentrations initially.

\section{Results}

Ten patients (six on vaccine, four on placebo) failed to complete the 12-month study. Results were analysed by comparing the change in each value at each time interval in the two groups of patients (those receiving vaccine and those receiving placebo) using Yates's $\chi^{2}$ test.

Symptom scores-There was no significant difference between the two groups at any time for any of the symptoms recorded.

Bronchodilator use-On entry to the trial aerosol bronchodilator (either salbutamol or terbutaline) was used significantly more often by those who received vaccine $(P<0.05)$ than by those on placebo, but no significant change in bronchodilator use was seen at any assessment period in either group.

Spirometry-There was a slight increase in $\mathrm{FEV}_{1}$ and FVC in both groups as the study progressed but no mean significant difference occurred between the groups at any time (table II)

Side effects-Local reactions occurred at the injection site after 82 of the 309 injections $(27 \%)$ in the vaccine group and after 129 of the

TABLE II-Mean change in dynamic lung volumes (litres; ambient temperature, pressure, and saturation)

\begin{tabular}{|c|c|c|c|c|c|c|c|c|c|c|c|c|c|c|}
\hline & & & \multicolumn{2}{|c|}{ Before } & \multicolumn{2}{|c|}{1 Month } & \multicolumn{2}{|c|}{3 Months } & \multicolumn{2}{|c|}{6 Months } & \multicolumn{2}{|c|}{9 Months } & \multicolumn{2}{|c|}{12 Months } \\
\hline & & & Vaccine & Placebo & Vaccine & Placebo & Vaccine & Placebo & Vaccine & Placebo & Vaccine & Placebo & Vaccine & Placebo \\
\hline $\begin{array}{l}\mathrm{FEV}_{1}(1) \\
\mathrm{FVC}_{(1)}\end{array}$ & $\because$ & . & $\begin{array}{l}1 \cdot 30 \\
2 \cdot 38\end{array}$ & $\begin{array}{l}1 \cdot 60 \\
2 \cdot 75\end{array}$ & $\begin{array}{r}+0.09 \\
+0.12\end{array}$ & $\begin{array}{l}-0.01 \\
+0.02\end{array}$ & $\begin{array}{l}+0.24 \\
+0.29\end{array}$ & $\begin{array}{l}+0.06 \\
+0.13\end{array}$ & $\begin{array}{l}+0.22 \\
+0.21\end{array}$ & $\begin{array}{l}+0.19 \\
+0.17\end{array}$ & $\begin{array}{l}+0.21 \\
+0.25\end{array}$ & $\begin{array}{l}+0.26 \\
+0.30\end{array}$ & $\begin{array}{l}+0.18 \\
+0.25\end{array}$ & $\begin{array}{l}+0.19 \\
+0.34\end{array}$ \\
\hline
\end{tabular}


342 injections $\left(38^{\circ}{ }_{0}\right)$ in the placebo group; the higher incidence of local reactions in the placebo group was statistically significant $(P<0.01)$. During the initial course of six injections seven patients in the vaccine group and five in the placebo group developed wheeze and dyspnoea within 48 hours of an injection. These episodes were mild, but at the next weekly visit a second injection of the same strength of vaccine (or matching placebo) was given, usually without ill effect, and the course was resumed at the following visit.

Skin and nasal challenge tests-Initital sensitivities are shown in table III. Sensitivity was considered to have decreased when a higher strength of $D$ pteronyssinus extract was required to provoke a positive reaction and increased when a lower strength of test solution was required. In both vaccine and placebo groups some patients showed a decrease in skin or nasal sensitivity, or both, others an increase, and others no change. There was no significant difference in skin or nasal sensitivity between the two groups at any assessment period.

TABLE III-Number of patients responding to skin and nasal challenge tests with extract of $\mathrm{D}$ pteronyssinus before treatment

\begin{tabular}{|c|c|c|c|c|c|c|c|c|}
\hline & & \multicolumn{4}{|c|}{ Skin test } & \multicolumn{3}{|c|}{ Nasal challenge } \\
\hline & & $0.005 \%$ & $0.04 \%$ & $0.33 \%$ & $1.2 \%$ & $0.005 \%$ & $0.04 \%$ & $0.33^{\prime \prime}$ \\
\hline $\begin{array}{l}\text { Vaccine group } \\
\text { Placebo group }\end{array}$ & $\begin{array}{l}\ldots \\
\cdots\end{array}$ & $\begin{array}{l}7 \\
13\end{array}$ & $\begin{array}{r}13 \\
8\end{array}$ & $\begin{array}{l}4 \\
7\end{array}$ & $\begin{array}{l}2 \\
1\end{array}$ & $\begin{array}{l}12 \\
19\end{array}$ & $\begin{array}{r}11 \\
6\end{array}$ & 2 \\
\hline
\end{tabular}

\section{Discussion}

This study of patients with fairly severe mite-sensitive asthma failed to show any benefit from a course of tyrosineadsorbed $D$ pteronyssinus vaccine. The overall incidence of local reactions-that is, swelling and itching-was higher in the placebo group, while general reactions-wheezing and dyspnoea -occurred within 48 hours of the injection in both groups.

Possibly our failure to show any benefit in asthmatics sensitive to house dust mite was due to the low strength of the vaccine but 400 Noon units was the highest strength available. D'Souza et $a l^{10}$ used a vaccine three times stronger than the commercially available aqueous extract, and some of their mite-sensitive patients benefited from the desensitisation. No subgroup of our patients benefited-for example, those with positive skin and nasal challenge responses to weak solutions of $D$ pteronyssinus extract showed no greater improvement in airways obstruction than those on placebo.

We thank Messrs Bencard for supplying the vaccine, Miss Jackie Urwin for statistical analysis, and Mrs Leys, Mrs MacAulay, and $\mathrm{Mr}$ David McKenzie for technical help.

Requests for reprints should be addressed to Dr K N V Palmer, University Department of Medicine, Foresterhill, Aberdeen AB9 2ZD.

\section{References}

${ }^{1}$ Voorhorst, R, Spieksma-Boezeman, M I A, and Spieksma, F T M, Allergie und Asthma, 1964, 10, 329

2 Pepys, J, Chan, M, and Hargreave, F E, Lancet, 1968, 1, 1270.

${ }^{3}$ Maunsell, K, Hughes, A M, and Wraith, D C, Practitioner, 1970, 205, 779.

${ }^{4}$ McAllen, M K, Assem, E S K, and Maunsell, K, British Medical fournal, 1970, 2, 501.

${ }^{5}$ Rao, V R M, et al, Clinical Allergy, 1975, 5, 209.

${ }^{6}$ British Thoracic and Tuberculosis Association, British Medical fournal, 1968, 3, 774.

' Aas, K, Acta Paediatrica Scandinavica, 1971, 60, 264.

${ }^{8}$ Maunsell, K, Wraith, D G, and Hughes, A M, Lancet, 1971, 1, 967

${ }^{9}$ Smith, A P, British Medical fournal, 1971, 4, 204.

10 D'Souza, M F, et al, Clinical Allergy, 1973, 3, 177.

\section{SHORT REPORTS}

\section{Quinaband-induced thrombocytopenic purpura in a patient with myxoedema coma}

Topical application of quinine analogues, unlike oral administration, has only once been reported to have caused thrombocytopenia. ${ }^{1}$ It occurred after one month's treatment with a hydrocortisonehydroxyquinoline cream and responded to prednisone. I report a further such episode that occurred after applying Quinaband dressings. The case highlights the severe systemic reactions that may follow the use of such a seemingly innocuous preparation. Quinaband contains zinc oxide paste $9 \cdot 25^{\circ} \%$, chloroiodohydroxyquinoline $1{ }^{\circ}$, calamine $5.75^{\circ} \mathrm{o}$, gum acacia $18.5^{\circ} \mathrm{o}$, boric acid $2^{\circ} \%$, glycerin $27^{\circ} \mathrm{o}$, prophyl hydroxybenzoate $0.0625^{\circ}{ }_{0}$, and water to $100^{\circ}{ }_{0}^{\circ}$.

\section{Case report}

A 68-year-old woman had attended another hospital for eight years for varicose ulcers and myxoedema. She took her thyroxine haphazardly and was admitted to this hospital in November 1974 in a confused state. This soon improved when she took her thyroxine regularly.

On 12 November 1975 she was readmitted for surgical treatment of extensive bilateral deep leg ulcers (right $17 \times 11 \mathrm{~cm}$, left $19 \times 20 \mathrm{~cm}$ ). She was found to have slow mental responses, was pale, and looked myxoedematous with a hoarse voice and dry skin. Her pulse rate was $60 / \mathrm{min}$ and regular, and her blood pressure $80 / 50 \mathrm{~mm} \mathrm{Hg}$. She was treated with her usual thyroxine, Multivite, and ferrous sulphate tablets, and Quinaband dressings were applied to the legs. She became drowsy and, five days after admission, lapsed into coma, her temperature dropping to $32 \cdot 2^{\circ} \mathrm{C}$ and her pulse rate to $40 / \mathrm{min}$ Myxoedema coma was diagnosed and confirmed by a serum thyroxine of $10 \mathrm{nmol}(7.8 \mu \mathrm{g}) / 1$ (normal $60-160 \mathrm{nmol}(47-124 \mu \mathrm{g}) / \mathrm{l})$, a serum triiodothyronine of $0.5 \mathrm{nmol}(0.3 \mu \mathrm{g}) / 1$ (normal $1.4-3.0 \mathrm{nmol}(0.9-2.0 \mu \mathrm{g}) / \mathrm{l})$, and a serum thyrotrophin-stimulating hormone level of $45 \mathrm{mU} / \mathrm{l}$ (normal up to
$5 \mathrm{mU} / 1)$. Serum cortisol was normal. $X$-ray films of the chest showed basal consolidation, and the sputum grew Staphylococcus aureus.

She was treated with triiodothyronine $20 \mu \mathrm{g}$ daily, intravenous hydrocortisone $100 \mathrm{mg}$ six-hourly, and intramuscular ampicillin and flucloxacillin. Her heart was monitored, and her body temperature rose gradually. Her platelet count fell, however (see figure), and purpura was noted on the chest. She was transfused with 2 units of packed cells but her platelet count continued to fall, and on 23 November haematuria and nose bleeds occurred. Despite the adverse haematological picture her general condition improved, and she had regained consciousness on 21 November and could take her treatment by mouth.

Further investigation on 23 November showed normal prothrombin and bleeding times and normal levels of fibrinogen degradation products. Marrow biopsy showed plentiful megakaryocytes but poor platelet formation. Bilirubin

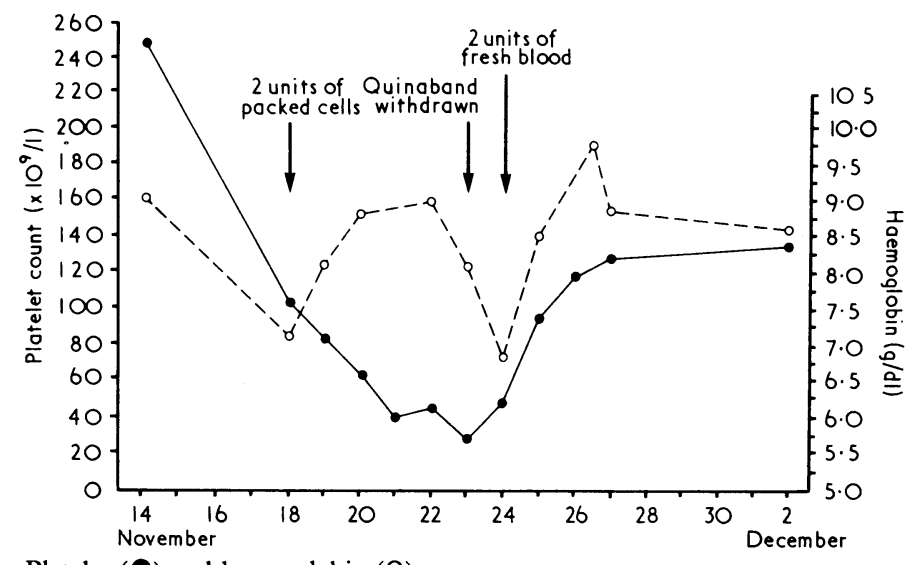

Platelet (O) and haemoglobin $(O)$ responses to treatment.

Conversion: SI to traditional units-Platelet count: $20 \times 10^{9} / 1=20000 / \mathrm{mm}^{3}$. 